\title{
Large-Scale WEEE Recycling Integrated in an Ore-Based Cu-Extraction System
}

\author{
Andreas Lennartsson $^{1}$ (D) Fredrik Engström ${ }^{1} \cdot$ Caisa Samuelsson $^{1} \cdot$ Bo Björkman ${ }^{1} \cdot$ Joachim Pettersson $^{2}$
}

Published online: 1 February 2018

(C) The Author(s) 2018. This article is an open access publication

\begin{abstract}
At Boliden's Rönnskär smelter, WEEE is smelted in a Kaldo process and the black copper, together or without the slag, is charged to the PS converter. This process route has proven to be a viable way to obtain a high WEEE smelting capacity in an originally ore-based process system. Experience shows that the slag in the PS converter is usually not fully liquid, and the amount of solids present in the slag increases due to introduction of slag and black copper from WEEE smelting. The effect of increased content of $\mathrm{Al}_{2} \mathrm{O}_{3}$ and $\mathrm{Cr}$ in the slag on the liquidus temperature has been calculated using FactSage both for the converter slag and for the slag in the electric smelting furnace. The potential of changed slag chemistry is discussed. The consequences of the applied praxis on the removal of Antimony in the converter have been modeled using SimuSage.
\end{abstract}

Keywords WEEE recycling $\cdot$ Integrated smelter $\cdot$ Challenges $\cdot$ Slag influence

\section{Introduction}

WEEE has for several decades been an important raw material for several copper smelters due to its content of mainly copper and precious metals. Early on, scrap from WEEE recycling came mainly from scrapped mainframe computers, switchboards, and other telecommunication equipment, etc. and was characterized by high content of both copper and precious metals. Today the amount of available WEEE scrap is much higher and continuously increasing; however, it contains a much lower content of the valuable metals that must cover the cost of recycling. The number of small electrical appliances containing electrical and/or electronic parts is ever increasing but with a low overall metal content and very low amount of precious metals. This necessitates an efficient system for the whole recycling chain and, not least, for the smelting operation.

In Sweden, the collection of consumer goods that belong to groups where producer responsibility applies is

The contributing editor for this article was Bernd Friedrich.

Andreas Lennartsson

lenann@1tu.se

1 Luleå University of Technology, 97187 Luleå, Sweden

2 Boliden Mineral AB, 93233 Skelleftehamn, Sweden organized through different material companies. The company responsible for the collection of WEEE is ElKretsen. In 2015 about 74 ktonne of WEEE was collected through El-Kretsen [1]. Looking at the trend from 2012, the amount in tonnes is decreasing, although the number of appliances is increasing as heavier goods such as old-style thick CRT television sets, are decreasing in number.

The WEEE Directive in Europe currently sets a minimum collection target of $4 \mathrm{~kg}$ per year per inhabitant for WEEE from households [2]. In the Nordic countries, the collection rate was more than $8 \mathrm{~kg}$ per capita and year; however, the rate is decreasing, as stated above. According to EU statistics, the amount collected in Europe is growing $3-5 \%$ per year, contrary to what is seen right now in Sweden. According to estimates, about one-third of the amount of WEEE generated is collected and recycled in a proper way. The total amount of WEEE put on the market within EU27 + Norway, but not including Spain, Italy, and Cyprus, was approximately 7900 ktonne in 2014, corresponding to about $19 \mathrm{~kg}$ per capita.

Data on how, and the extent to which, WEEE is recycled in different companies throughout the world are scarce for obvious reasons; this is an area where large competition exists regarding the best parts of the scrap. It is, however, clear that recycling of WEEE is practiced in several copper smelters throughout the world. In a pyrometallurgical 
copper extraction, WEEE can be introduced in several different ways:

1. Smelting and refining in a process specially designed or adapted to extract copper and other metals from WEEE scrap into a blister copper or crude copper bullion that is further refined into pure copper and where other metals contained in WEEE are extracted to a varying degree. Examples from Europe include the operation of Metallo [3], the operation of the Lünen plant belonging to Aurubis [4], Umicore operations in Hoboken [5, 6], and Montanwerke Brixlegg in Austria [7], all of which are totally directed towards recycling, but to what extent WEEE is part of the recycled materials is not given. Umicore has totally shifted the operations at the Hoboken plant towards recycling and in total about 350 ktonne of precious metal-bearing secondary materials of all types is used. The plant is one of the world's largest precious metals recycling facilities. The amount of raw materials processed at the Aurubis Lünen plant is about 300 ktonne yearly. In some cases, also the light organic fractions from shredding operations have been tested for use as replacement of coal, etc., as an energy source and for reduction [8].

2. Smelting of WEEE in a special process step giving a black copper and a slag. Either can both phases or only the black copper be further processed in existing process steps for treating ore-based raw materials, e.g., as it is carried out in Boliden's Rönnskär plant.

3. Using WEEE as part of the raw-material mix in a process system originally intended to mainly treat orebased raw materials. The purpose is to utilize existing free capacities with respect to energy, impurities, and refining. One example is the Noranda smelter in Canada.

Several reviews of concepts for recycling of WEEE have been published recently, e.g., [9, 10], including not only pyrometallurgical routes but also other techniques, traditional hydrometallurgical processing, bio-hydrometallurgy, electrochemical, supercritical, vacuum, and molten salt techniques. As stated in Ref. [9], the processing of WEEE is driven by the economics of precious metal recovery, at the same time as maximum recovery of the base metals contained in WEEE is obtained. This can be achieved in the traditional pyrometallurgical base metals and recycling processes and, so far, other techniques have not been used in full-scale operation.

In addition to copper and precious metals, by using WEEE as a raw material in copper extraction, considerable amounts of other metals are introduced. Not only possibly valuable elements such as $\mathrm{Sn}$, In, etc., but also $\mathrm{Sb}$ and $\mathrm{Al}$. Antimony content contributing considerably to the total impurity load of this element and Aluminum forming alumina, which together with other high-melting oxides containing, e.g., chromium, give a slag with very highmelting point and viscosity, endangering a good slag/matte/ metal separation. The purpose of this paper is to describe and analyze the consequences when large-scale WEEE is integrated in an ore-based $\mathrm{Cu}$-extraction system.

\section{Overview of WEEE Recycling in the Process System at Boliden, Rönnskär Plant}

Boliden Mineral is a mining company and the Rönnskär smelter plant was built in the early 1930s to treat in-house concentrate produced at Boliden's mines in the Skelleftea vicinity. Copper concentrate produced at mines in the Skellefteå field are in general very complex as regards base metals ( $\mathrm{Cu}, \mathrm{Zn}, \mathrm{Pb}$ ) and "impurities" (As, Sb, Bi, Se, Te, $\mathrm{Hg}$, etc.). This is the reason why the Rönnskär plant flow sheet today does not resemble that of other ordinary copper smelters, cf., Fig. 1. Boliden was in the past forced to develop some special processes (Zinc fuming plant, Lead Kaldo plant, PGM Kaldo, etc.) to be able to treat the complex concentrates. Later on, in the beginning of the 1970s Boliden also started to treat some complex secondary raw materials, like copper zinc ash from the brass industry, steel mill dust, and WEEE from different collectors around the world. The newest E-Kaldo plant at Rönnskär can process at least 100,000 tonnes of WEEE annually.

The E-Kaldo plant is a very flexible unit. Coarse WEEE can be charged batch-wise by a skip hopper, and finefragmentized WEEE can be charged continuously by lance during the smelting operation. The E-Kaldo plant does not produce a final product for the common market. Instead, it produces different intermediate products for the Rönnskär smelter plant, depending on the downstream capacity. The E-Kaldo plant can produce liquid black copper with separated liquid slag or liquid black copper together with incinerated oxides. The liquid black copper can then either be charged to the PS converters or be granulated as an intermediate cooling material for later use. If the impurity level ( $\mathrm{Cr}, \mathrm{Al}, \mathrm{Mg}$, etc.) in the PS converter slag is not too high, it is then possible to feed the PS converters with liquid black copper together with incinerated oxides.

WEEE is from a smelter's perspective a very heterogeneous raw material in several aspects. The composition of WEEE on the market varies considerably with respect to the content of valuable metals, other metals, oxides, impurities, and plastics. Also, the physical form and the particle size distribution vary greatly from one delivery to another. This is not only a metallurgical process challenge, 


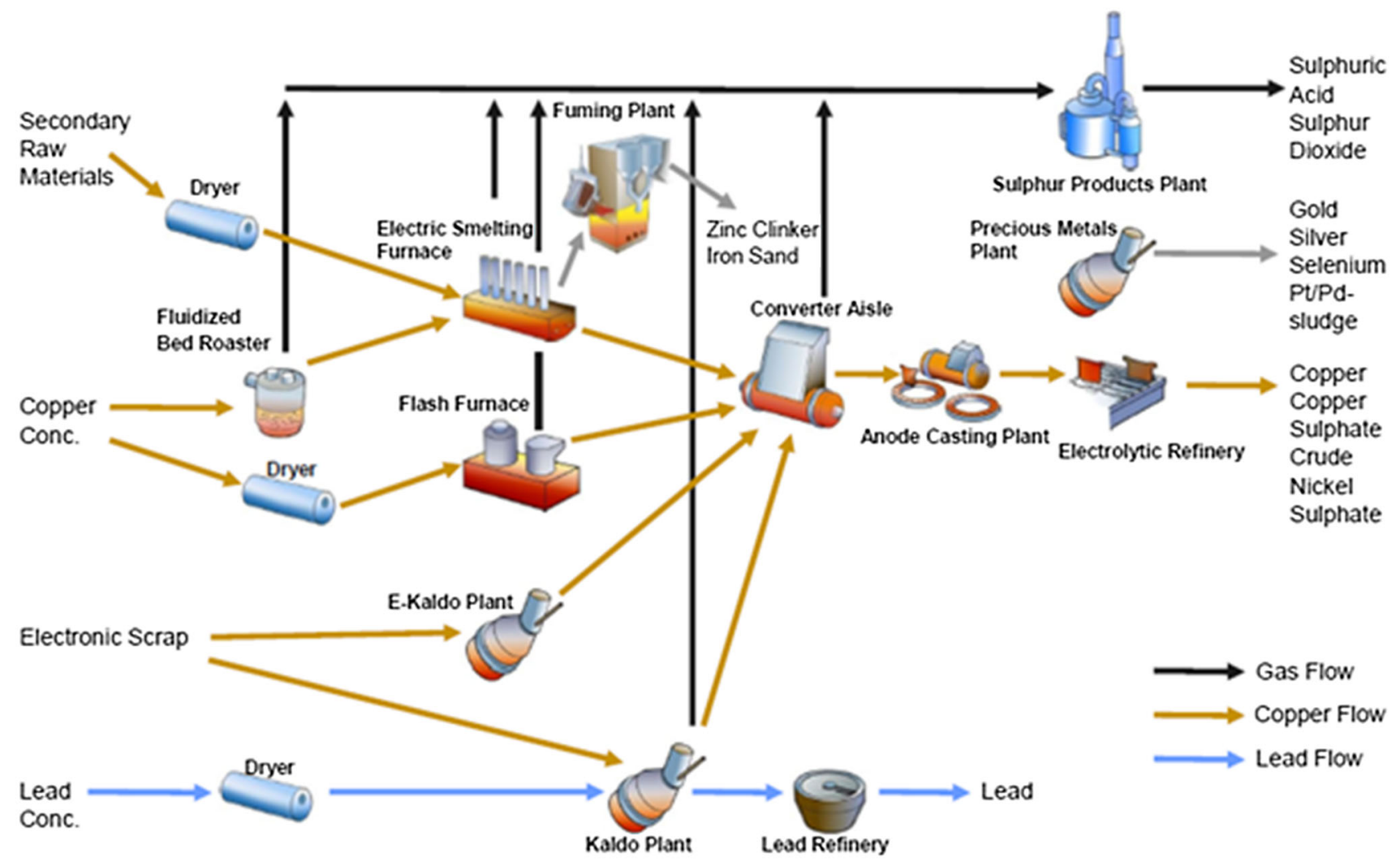

Fig. 1 The process system at Boliden's Rönnskär plant (Color figure online)

but also a sampling and WEEE valuation challenge for the smelter.

\section{Methods}

\section{Thermodynamic Calculations of Liquidus Temperatures of the Slags}

Thermodynamic calculations have been carried out using FACTSAGE 6.4, and using the databases Fact PS and FToxid. The base slag compositions used in the calculations are given in Tables 1 and 2. Calculated compositions for converter slag and for ESF (Electric Smelting Furnace) slag given in Table 1 are the slag compositions obtained in the calculations when a fixed oxygen partial pressure is used, $p\left(\mathrm{O}_{2}\right)=10^{-6}$ for converter and $10^{-9}$ for ESF slag, together with the base composition. For the modeling of a calcium ferrite slag, two compositions for such a slag were taken from literature $[11,12]$. Calculations were performed as precipitation target calculations.

\section{Model for a PS Converter}

The model was built using thermodynamic data from the FactSage 5.5 databases [13] Fact 53, FToxid, and FTmisc, supplemented with additional data for some of the gaseous species from Ref. [14]. The non-equilibrium conditions occurring by having an airstream injected on one side of the converter at one level of the bath were simulated by considering several segments of the reactor and distributing the phases formed in between segments according to their densities. The model was implemented in the SimuSage environment. Details of the model are given elsewhere [15].

To simulate the influence of the converting step in which the black copper is introduced on the distribution of $\mathrm{Sb}$ and $\mathrm{Bi}$ to slag and gas, data on $\mathrm{Sb}$ and $\mathrm{Bi}$ in metal, matte, and slag were estimated from literature data. Details of this modeling are described in Ref. [16]. 
Table 1 Slag analysis used as starting point in the calculations of liquidus temperatures

\begin{tabular}{|c|c|c|c|c|c|c|}
\hline & \multicolumn{6}{|c|}{ Slag composition (wt $\%$ ) } \\
\hline & \multicolumn{3}{|c|}{ Converter } & \multicolumn{3}{|l|}{ EFS } \\
\hline & Original & Normalized & Calculated & Original & Normalized & Calculated \\
\hline $\mathrm{Al}_{2} \mathrm{O}_{3}$ & 3.8 & 4.6 & 4.1 & 3.7 & 4.7 & 4.2 \\
\hline $\mathrm{CaO}$ & 1.3 & 1.6 & 1.4 & 2.4 & 3.0 & 2.7 \\
\hline $\mathrm{Cr}_{2} \mathrm{O}_{3}$ & 0.7 & 0.9 & 0.8 & 0.3 & 0.3 & 0.3 \\
\hline Fetot & 35.5 & 43.0 & & 28.7 & 36.3 & \\
\hline $\mathrm{Fe}_{2} \mathrm{O}_{3}$ & & & 45.7 & & & 41.6 \\
\hline $\mathrm{FeO}$ & & & 3.7 & & & 0.8 \\
\hline $\mathrm{MgO}$ & 0.5 & 0.6 & 0.5 & 0.9 & 1.1 & 1.0 \\
\hline $\mathrm{NiO}$ & 0.5 & 0.7 & 0.6 & 0.1 & 0.1 & 0.1 \\
\hline $\mathrm{PbO}$ & 3.9 & 4.7 & 4.2 & 1.3 & 1.7 & 1.5 \\
\hline $\mathrm{SiO}_{2}$ & 28.4 & 34.4 & 30.5 & 29.8 & 37.7 & 34.1 \\
\hline $\mathrm{ZnO}$ & 7.8 & 9.5 & 8.4 & 11.9 & 15.1 & 13.7 \\
\hline Sum & 82.5 & 100.0 & 100.0 & 79.1 & 100.0 & 100.0 \\
\hline $\mathrm{Fe} / \mathrm{SiO}_{2}$ & 1.25 & 1.25 & 1.25 & 0.962 & 0.962 & 0.962 \\
\hline
\end{tabular}

Analysis given is the average slag composition from 2012 at Boliden's Rönnskär plant. ESF stands for Electric Smelting Furnace
Table 2 Slag analysis used as starting point in the calculations of liquidus temperatures for calcium-ferrite-based slags $[11,12]$

\begin{tabular}{lllll}
\hline Lime-based slags/wt\% & $\mathrm{CaO}$ & $\mathrm{Fe}_{2} \mathrm{O}_{3}$ & $\mathrm{FeO}$ & $\mathrm{CaO} / \mathrm{Fe}_{2} \mathrm{O}_{3}$ \\
\hline Case 1 & 25 & 60 & 15 & 0.42 \\
Case 2 & 21.5 & 49 & 29.5 & 0.44 \\
\hline
\end{tabular}

\section{Results and Discussion}

\section{Process Data}

It is a general observation that the slag in the PS converter is saturated with spinel, generally labeled magnetite, due to the high oxygen partial pressures during converting. In the operation of the Rönnskär plant it has also been observed that the amount of solid slag in the converter is increased due to the introduction of black copper, often together with the slag, from smelting of WEEE. Introducing increased amounts of WEEE in the process scheme may result in increased load of high-melting spinel forming oxides such as $\mathrm{Cr}_{2} \mathrm{O}_{3}$ and $\mathrm{Al}_{2} \mathrm{O}_{3}$. At the same time, it is of interest to keep the zinc content in the ESF slag at a high level for efficient recovery of the zinc in the fuming plant. As shown in Fig. 1, the black copper, and usually also the slag, from smelting in the E-Kaldo is taken to the PS converter. As the slag from the converter is recycled to the Electric Smelting Furnace, changed slag composition due to WEEE recycling will influence the operation of both processes, PS converter and Electric Smelting Furnace and, finally, also the operation of the fuming plant. Characterization of samples of the bottom build-up in the ESF obtained during excavation of the furnace showed that the bottom build-up in the furnace partly consists of high-melting spinel phases [17]. The composition of the spinel phases varies, but always contains an increased amount of the refractory oxides: alumina and chromium oxides. The influence of changed slag composition on the liquidus temperatures of both converter slag and ESF slag due to introduction of WEEE is therefore crucial for the operation.

The effect an increased amount of WEEE has on the processes at the Rönnskär plant is shown in Figs. 2, 3, and 4. The products from smelting WEEE are, as described earlier, charged to the Peirce-Smith converters. Figure 2 shows the content of $\mathrm{Al}_{2} \mathrm{O}_{3}$ and $\mathrm{Cr}$ in converter slag, respectively. As shown, there is an increase in both $\mathrm{Al}_{2} \mathrm{O}_{3}$ and $\mathrm{Cr}$ up until the year 2012; thereafter, the $\mathrm{Al}_{2} \mathrm{O}_{3}$ content levels out, whereas the $\mathrm{Cr}$ content decreases.

The converter slag is recycled to the ESF, as shown in Fig. 1. As a consequence, the changed slag composition in the converter slag can also affect the ESF as well as the following fuming plant. Figure 3 shows the monthly average slag temperature in the ESF. The data show the same trend as $\mathrm{Al}_{2} \mathrm{O}_{3}$ in converter slag, i.e., an increased average slag temperature until year 2012 and, thereafter, stabilization. An increased amount of either aluminum or chromium is expected to give rise to an increased liquidus temperature of the slag.

One of the final products from the fuming plant is the iron sand, i.e., the fayalite slag from smelting in the ESF. 

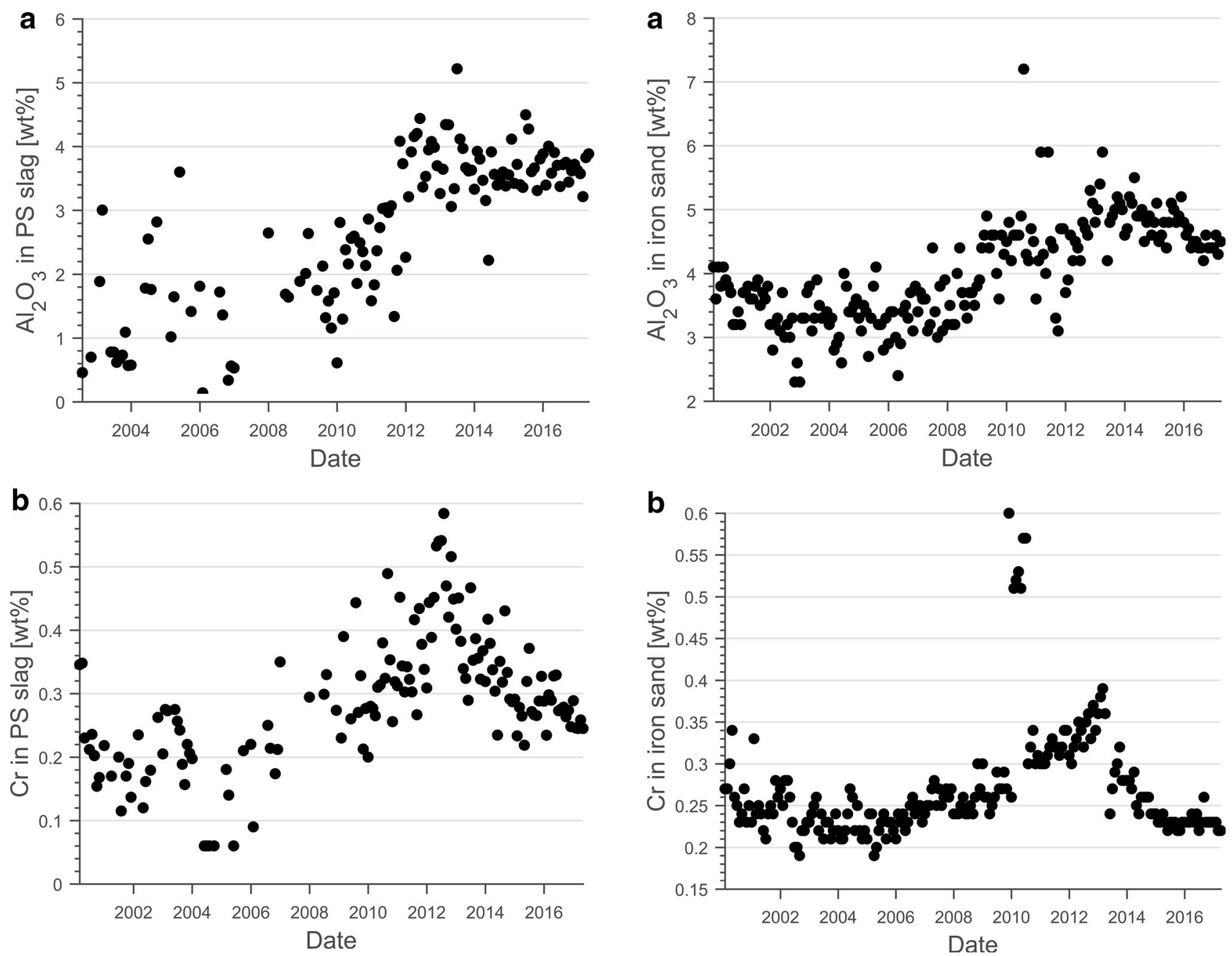

Fig. 2 Monthly average of $\mathbf{a} \mathrm{Al}_{2} \mathrm{O}_{3}$ and $\mathbf{b} \mathrm{Cr}$ content in slag from Peirce-Smith converter (wt\%)

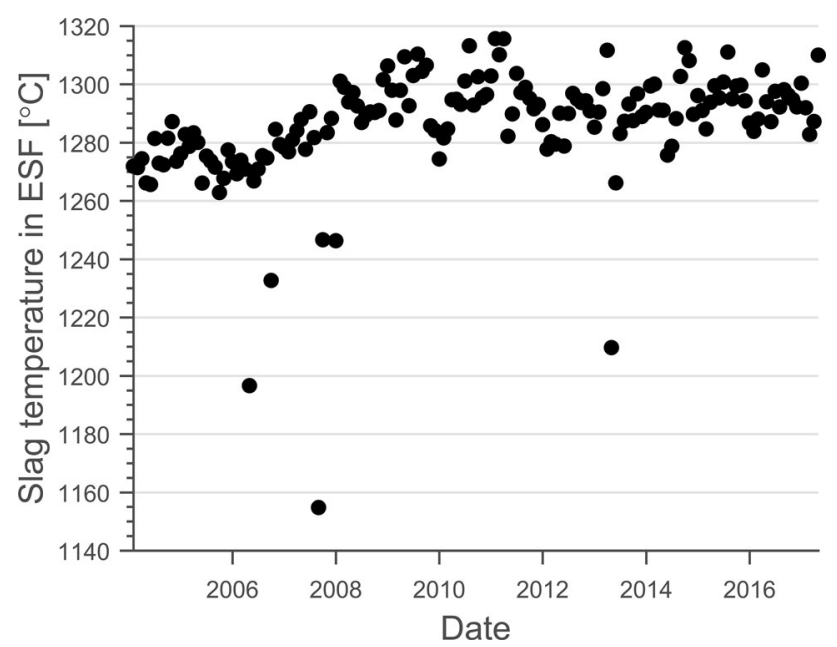

Fig. 3 Monthly average of ESF slag temperature $\left({ }^{\circ} \mathrm{C}\right)$

As shown in Fig. 4, the contents of $\mathrm{Al}_{2} \mathrm{O}_{3}$ and $\mathrm{Cr}$ follow the same trend as in the converter slag.

Fig. 4 Monthly average of $\mathrm{Al}_{2} \mathrm{O}_{3}$ and $\mathrm{Cr}$ content in iron sand (wt\%)

\section{Thermodynamic Calculations of Liquidus Temperatures}

The effect of varying slag compositions due to increased amount of refractory oxides contained in WEEE was estimated using FACTSAGE 6.4. Calculations have been performed to estimate the effect of the contents of $\mathrm{Cr}_{2} \mathrm{O}_{3}$, $\mathrm{ZnO}$, and $\mathrm{Al}_{2} \mathrm{O}_{3}$ in both slags on the liquidus temperatures, and also to estimate to what extent an increased content of lime in the slag will change the influence on liquidus temperatures. Although the calculated liquidus temperatures not may reflect the actual ones precisely, as some minor components are omitted, the relative trends are most likely correct.

\section{ESF Slag}

Calculations on the smelting slag have been carried out with the original slag composition, as given in Table 1 as a 
base. When varying the content of $\mathrm{Cr}_{2} \mathrm{O}_{3}, \mathrm{Al}_{2} \mathrm{O}_{3}$, and $\mathrm{ZnO}$, other components have been changed in such a way as to keep the proportions of all other components constant. Calculations were carried out at different ratios of $\mathrm{Fe} / \mathrm{SiO}_{2}$ in the slag at a constant oxygen partial pressure $p\left(\mathrm{O}_{2}\right)$ of $10^{-9}$. Figure 5 shows the effect on liquidus temperatures.

The calculations show that a low amount of chromium in the slag already increases the liquidus temperature considerably, whereas the influence of aluminum and zinc in the slag is much less and, for increased zinc content at high $\mathrm{Fe} / \mathrm{SiO}_{2}$ ratio, the increase in liquidus temperature is
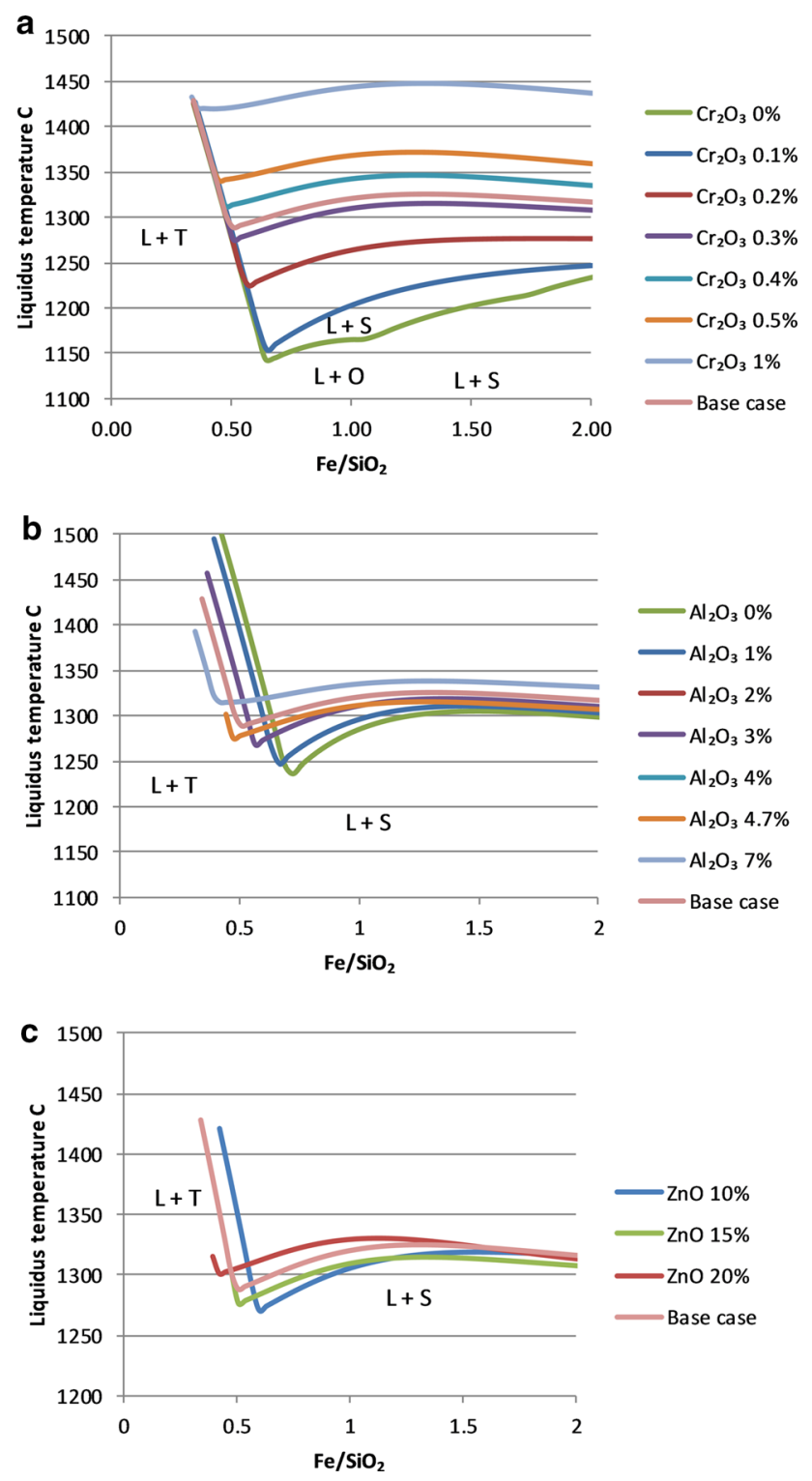

Fig. 5 Effect of $\mathrm{Cr}, \mathrm{Al}$, and $\mathrm{Zn}$ contents on the liquidus temperature of ESF slag at varying quotients $\mathrm{Fe} / \mathrm{SiO}_{2}$ at $\mathrm{p}\left(\mathrm{O}_{2}\right)=10^{-9} . \mathrm{L}+\mathrm{T}$, $\mathrm{L}+\mathrm{S}$, and $\mathrm{L}+\mathrm{O}$ stand for saturation of liquid slag with tridymite, spinel, and olivine phase, respectively. Base case corresponds approximately to the lines for $0.3 \% \mathrm{Cr}_{2} \mathrm{O}_{3}, 4.7 \% \mathrm{Al}_{2} \mathrm{O}_{3}$, and $15 \%$ $\mathrm{ZnO}(\mathrm{wt} \%)$ (Color figure online) very minor. Also, for aluminum at high $\mathrm{Fe} / \mathrm{SiO}_{2}$ ratio, the change in liquidus temperature is very small up to about 5 wt $\% \mathrm{Al}_{2} \mathrm{O}_{3}$ in the slag. The lowest liquidus temperature is in all cases obtained at an $\mathrm{Fe} / \mathrm{SiO}_{2}$ ratio of 0.6 or less. The temperature of this slag is generally assumed to be at about $1250-1300{ }^{\circ} \mathrm{C}$. At an $\mathrm{Fe} / \mathrm{SiO}_{2}$ ratio of about 0.9, the slag can dissolve about $0.3 \mathrm{wt} \% \mathrm{Cr}_{2} \mathrm{O}_{3}$ but would be saturated with zinc at a content of $10 \mathrm{wt} \% \mathrm{ZnO}$ and $0 \mathrm{wt} \% \mathrm{Al}_{2} \mathrm{O}_{3}$.

It should be pointed out that taking, e.g., the curves for 0 wt\% $\mathrm{Cr}$ and $0 \mathrm{wt} \% \mathrm{Al}$, they are not identical, e.g., the calculation for $0 \mathrm{wt} \% \mathrm{Cr}$ contains $\mathrm{Al}$ corresponding to the base case and vice versa. For comparison, the calculated liquidus temperatures for the base case are shown in Fig. 5. For a slag not containing any $\mathrm{Al}_{2} \mathrm{O}_{3}, \mathrm{Cr}_{2} \mathrm{O}_{3}$, and $\mathrm{ZnO}$, liquidus temperature is given in Fig. 6. As shown in Fig. 5, already for the base case the slag is not fully liquid at $1300{ }^{\circ} \mathrm{C}$ at an $\mathrm{Fe} / \mathrm{SiO}_{2}$ ratio of 0.96 , whereas a slag without any $\mathrm{Al}_{2} \mathrm{O}_{3}, \mathrm{Cr}_{2} \mathrm{O}_{3}$, and $\mathrm{ZnO}$ would be liquid over a broad range of $\mathrm{Fe} / \mathrm{SiO}_{2}$ ratios already at $1200{ }^{\circ} \mathrm{C}$, as shown in Fig. 6.

\section{PS-Converter Slag}

As for the ESF slag, calculations on the converter slag have been carried out with the original slag composition, as given in Table 1 as a base, varying the content of $\mathrm{Cr}_{2} \mathrm{O}_{3}$, $\mathrm{Al}_{2} \mathrm{O}_{3}$, and $\mathrm{ZnO}$, increasing and decreasing, at different ratios of $\mathrm{Fe} / \mathrm{SiO}_{2}$ in the slag at a constant oxygen partial pressure $p\left(\mathrm{O}_{2}\right)$ of $10^{-6}$. Figure 7 shows the effect on liquidus temperatures.

It is quite clear that increased content of all three oxides gives considerably higher liquidus temperature of the slag, the effect of a small increase already in chromium content being highest. Assuming a temperature of the slag of $1300{ }^{\circ} \mathrm{C}$, we can also see that the calculations predict the slag to be saturated with spinel at $\mathrm{Fe} / \mathrm{SiO}_{2}$ ratios higher

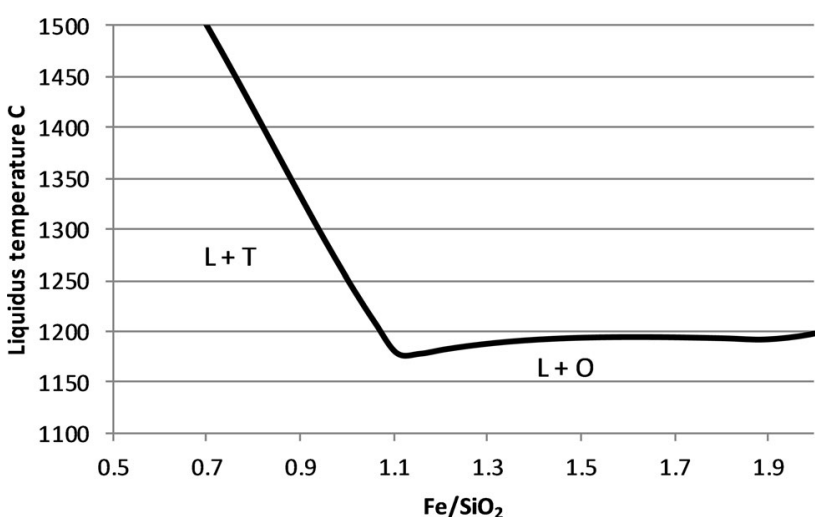

Fig. 6 Liquidus temperature of ESF slag, for a $\mathrm{Al}_{2} \mathrm{O}_{3^{-}}, \mathrm{Cr}_{2} \mathrm{O}_{3^{-}}$, and $\mathrm{ZnO}$-free slag at varying quotients $\mathrm{Fe} / \mathrm{SiO}_{2}$ at $\mathrm{p}\left(\mathrm{O}_{2}\right)=10^{-9}$. $\mathrm{L}+\mathrm{T}$ and $\mathrm{L}+\mathrm{O}$ stand for saturation of liquid slag with tridymite and olivine phase, respectively 

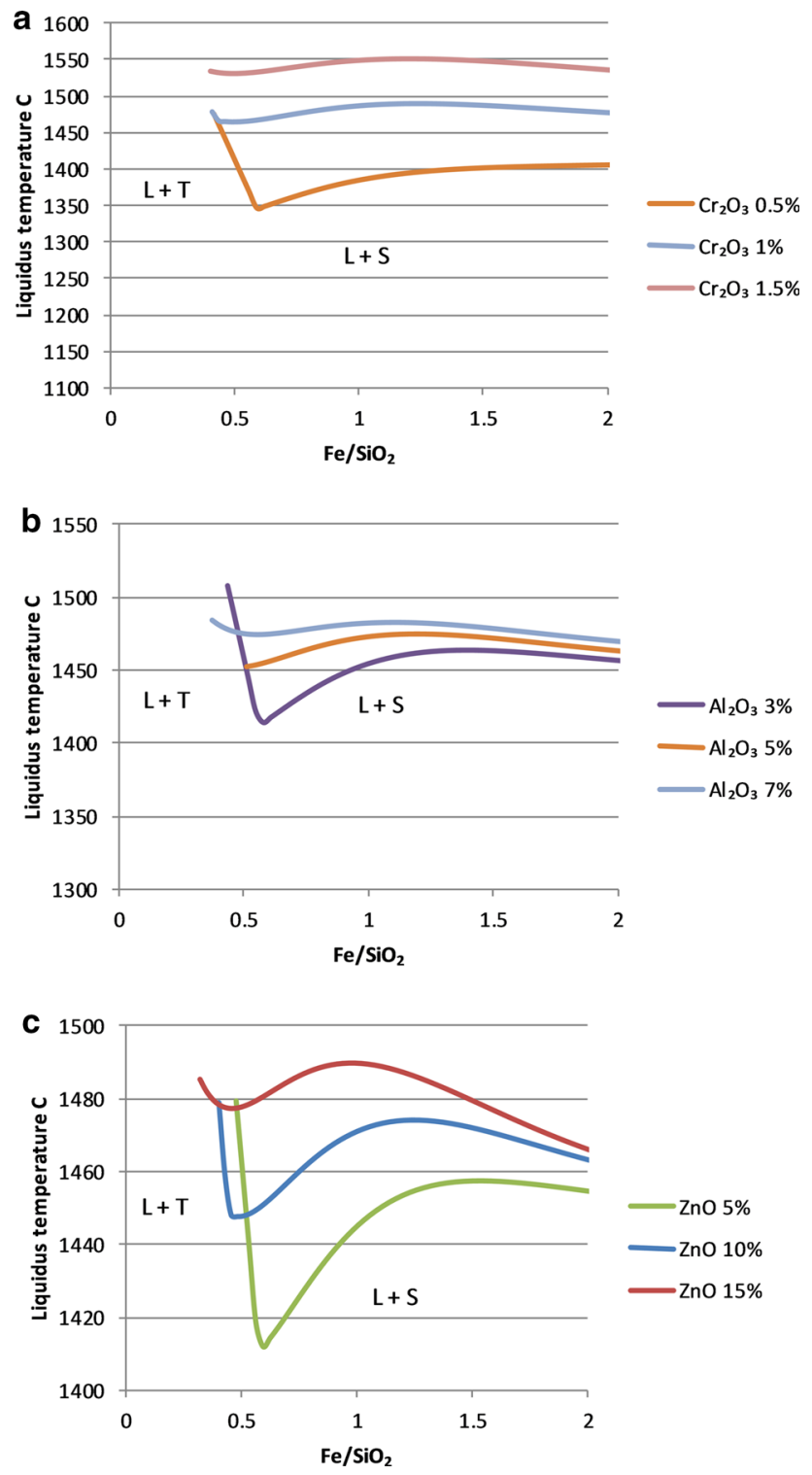

Fig. 7 Effect of $\mathrm{Cr}, \mathrm{Al}$, and $\mathrm{Zn}$ content on the liquidus temperature of converter slag at varying quotients $\mathrm{Fe} / \mathrm{SiO}_{2}$ at $\mathrm{p}\left(\mathrm{O}_{2}\right)=10^{-6}$. $\mathrm{L}+\mathrm{T}$ and $\mathrm{L}+\mathrm{S}$ stand for saturation of liquid slag with tridymite and spinel phase, respectively. Base case corresponds to approximately $1 \%$ $\mathrm{Cr}_{2} \mathrm{O}_{3}, 5 \% \mathrm{Al}_{2} \mathrm{O}_{3}$, and $10 \% \mathrm{ZnO}$ (wt $\%$ ) (Color figure online)

than 0.6, which is in good agreement with practical observations. The calculations also show that going from the "normal" case with $\mathrm{Fe} / \mathrm{SiO}_{2}=1.25$ towards a lower $\mathrm{Fe} /$ $\mathrm{SiO}_{2}$ ratio would decrease the liquidus temperature, the effect being highest at low content of $\mathrm{Cr}_{2} \mathrm{O}_{3}, \mathrm{Al}_{2} \mathrm{O}_{3}$, and $\mathrm{ZnO}$.

For comparison, the calculated liquidus temperatures for the base case as well as for the case with slag not containing any $\mathrm{Al}_{2} \mathrm{O}_{3}, \mathrm{Cr}_{2} \mathrm{O}_{3}$, and $\mathrm{ZnO}$ are given in Fig. 8. The figure shows clearly that for the base case, the slag is not fully liquid even at $1400{ }^{\circ} \mathrm{C}$ at any $\mathrm{Fe} / \mathrm{SiO}_{2}$ ratio, whereas a slag without any $\mathrm{Al}_{2} \mathrm{O}_{3}, \mathrm{Cr}_{2} \mathrm{O}_{3}$, and $\mathrm{ZnO}$ would be liquid at $1300{ }^{\circ} \mathrm{C}$ at a $\mathrm{Fe} / \mathrm{SiO}_{2}$ ratio between approximately 1 and 1.5 .

\section{Influence of Lime Content in the Slag}

The influence of $\mathrm{Al}_{2} \mathrm{O}_{3}$ and $\mathrm{Cr}_{2} \mathrm{O}_{3}$ on the liquidus temperature for a calcium ferrite-based slag has also been calculated. Two different cases have been considered: one with somewhat lower $\mathrm{CaO} / \mathrm{Fe}_{2} \mathrm{O}_{3}$ ratio and a $\mathrm{FeO}$ content of about $15 \mathrm{wt} \%$ and one with somewhat higher $\mathrm{CaO} /$ $\mathrm{Fe}_{2} \mathrm{O}_{3}$ ratio and about $29 \mathrm{wt} \% \mathrm{FeO}$. The base analysis for both cases is given in Table 2. On addition of alumina and chromium oxide, the amount of other components is varied such that the relative proportions are kept approximately constant. Results from these calculations are shown in Figs. 9 and 10.

The calculations show clearly that a calcium ferritebased slag is able to accept higher amount of chromium and aluminum, avoiding increased liquidus temperature of the slag, or possibly decreasing the liquidus temperature. The positive effect of a calcium ferrite slag is largest at a moderate content of two valent iron, $\mathrm{FeO}$.

\section{Influence on Distribution of Antimony and Bismuth}

With the introduction of WEEE in a copper smelting system, detrimental impurities are also introduced, not only slag-forming elements. The most dominant may be Sb, emanating from the flame retardants used in the electronic components. As long as the smelter has capacity for accepting the amount of impurities introduced, the consequences are minor. However, how these impurity elements behave in the copper smelting system depends on a number of parameters, not the least of which is the process step

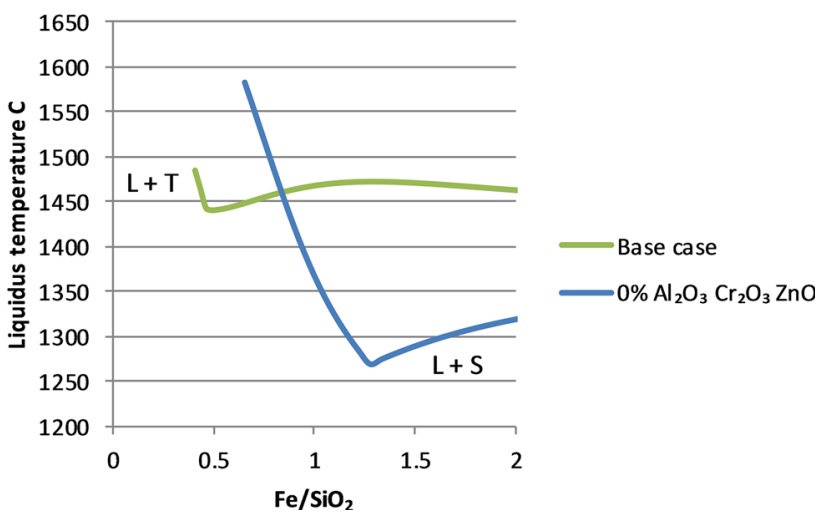

Fig. 8 Liquidus temperature of converter slag, base case, as well as for a $\mathrm{Al}_{2} \mathrm{O}_{3^{-}}, \mathrm{Cr}_{2} \mathrm{O}_{3^{-}}$, and $\mathrm{ZnO}$-free slag at varying quotients $\mathrm{Fe} / \mathrm{SiO}_{2}$ at $\mathrm{p}\left(\mathrm{O}_{2}\right)=10^{-6}$. $\mathrm{L}+\mathrm{T}$ and $\mathrm{L}+\mathrm{S}$ stand for saturation of liquid slag with tridymite and spinel phase, respectively (Color figure online) 


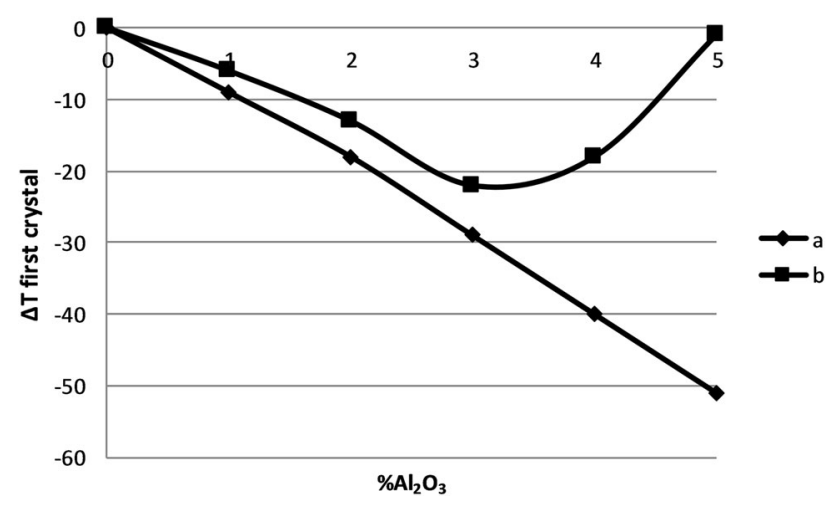

Fig. 9 Influence of $\mathrm{Al}_{2} \mathrm{O}_{3}$ content in a slag based on the system $\mathrm{CaO}-$ $\mathrm{FeO}-\mathrm{Fe}_{2} \mathrm{O}_{3}$ on the temperature for the first crystallization in the slag. $a \mathrm{CaO} / \mathrm{Fe}_{2} \mathrm{O}_{3}=0,42$ and $\mathrm{FeO}$ content between 14,3 and $15 \mathrm{wt} \%$, $b \mathrm{CaO} / \mathrm{Fe}_{2} \mathrm{O}_{3}=0.44$ and $\mathrm{FeO}$ content between 28 and $29.5 \mathrm{wt} \%$

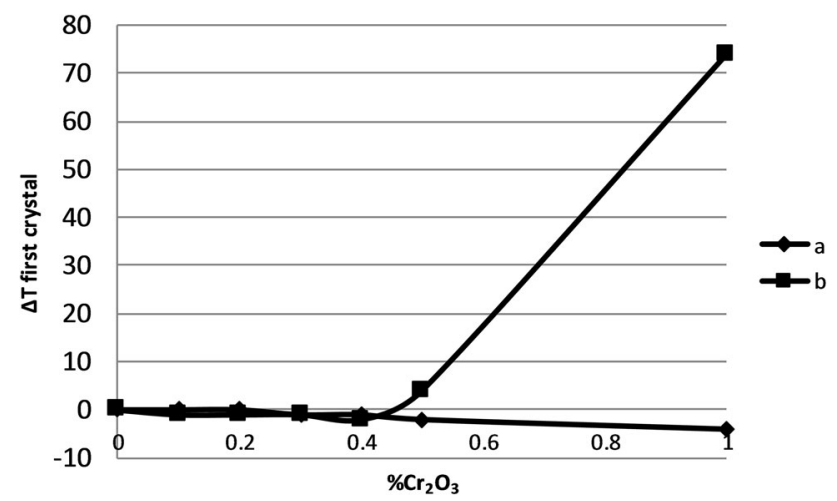

Fig. 10 Influence of $\mathrm{Cr}_{2} \mathrm{O}_{3}$ content in a slag based on the system $\mathrm{CaO}-\mathrm{FeO}-\mathrm{Fe}_{2} \mathrm{O}_{3}$ on the temperature for the first crystallization in the slag. $a \mathrm{CaO} / \mathrm{Fe}_{2} \mathrm{O}_{3}=0,42$ and $\mathrm{FeO}$ content between 14,3 and $15 \mathrm{wt} \%$, $b \mathrm{CaO} / \mathrm{Fe}_{2} \mathrm{O}_{3}=0.44$ and $\mathrm{FeO}$ content between 28 and $29.5 \mathrm{wt} \%$

during which the black copper is charged after smelting of the WEEE.

Lennartsson [15] has developed a non-equilibrium dynamic model to simulate the chemical and energy relations during a blow in a PS converter. This model has also been used to simulate the consequences of charging the black copper and slag from smelting of WEEE to different steps of converting [16]. Converting in a PS converter is usually carried out in a number of slag blowing (SB) steps with removal of slag and charging of new matte in between, until the converter is finally filled up with highgrade matte, white metal, and the copper blowing step can proceed. Ideally, there should only be matte and slag and no metal phase present during the slag blowing steps in order to maintain a high distribution of impurity elements to slag and gas, as many of the detrimental impurities have a high affinity to the liquid copper phase. By introducing the metallic black copper, a liquid metal phase will be present in the bottom of the furnace for shorter or longer time. Depending on the raw materials used in earlier steps, the matte charged to the PS converter can have considerably different sulfur contents and already be close to forming, or already containing, a metal phase. It was therefore deemed interesting to try to model the consequences of introducing the black copper in different slag blowing steps.

How close the charge is to forming a metal phase can be described by using the sulfur deficiency of the matte. Sulfur deficiency (SD) is the deviation of sulfur content from the pseudobinary $\mathrm{Cu}_{2} \mathrm{~S}-\mathrm{FeS}$ and can thus be calculated as

$\mathrm{SD}=X_{\mathrm{S}}-1 / 2 X_{\mathrm{Cu}}-X_{\mathrm{Fe}}$.

A positive value thus corresponds to a sulfur content on the sulfur-rich side of the pseudobinary $\mathrm{Cu}_{2} \mathrm{~S}-\mathrm{FeS}$. Figure 11 shows calculated values of $\mathrm{SD}$ for some of the cases considered by Lennartsson et al. [16].

Figure 11 shows that starting with a matte containing 65 wt $\% \mathrm{Cu}$ gives a quicker decrease in sulfur, and the influence of charging black copper on the sulfur deficiency is more pronounced. These calculations are based on "normal" matte compositions and not considering extreme cases with much lower sulfur content in the starting matte which could give rise to SD-values well on the negative side and thus a separation of a liquid metal phase. Furthermore, in these calculations it is assumed that the black

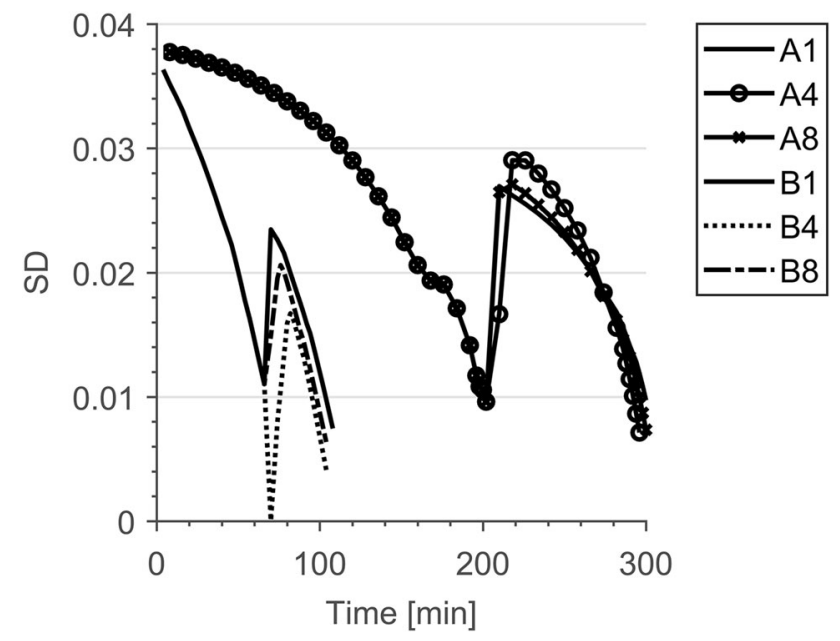

Fig. 11 Sulfur deficiency versus blowing time for some of the cases considered in Ref. [15]. A- and B-series corresponding to converting a matte with originally 45 and $65 \mathrm{wt} \% \mathrm{Cu}$, respectively. Variations of A and B-series correspond to different times for charging black copper and slag from WEEE smelting. For details, see Lennartsson et al. [16]. Reprinted from Thermodynamic process modeling of black copper addition to a Peirce-Smith converter: effect on the distribution of antimony and bismuth, Lennartsson et al., Mineral processing and Extractive Metallurgy (Trans. Inst. Min Metall. C), copyright The Institute of Materials, Minerals and Mining reprinted by permission of (Taylor \& Francis Ltd, http://www.tandfonline.com) 
copper additions are uniformly distributed in existing matte.

Figure 12 shows two cases where the antimony distribution between different cases has been calculated using the dynamic non-equilibrium PS-converter model [16]. The model predicts that upon addition of the black copper a liquid metal phase will prevail for a time. The distribution of antimony to the slag will at the same time decrease in accordance with what could be expected, impurities like $\mathrm{Sb}, \mathrm{Bi}$, and As having a high affinity to the liquid metal phase. The same modeling showed that elimination of $\mathrm{Bi}$ is mainly through vaporization [16] and thereby dependent on a long blowing time, i.e., a low matte grade at start, also in very good agreement with general copper making knowledge. Addition of black copper to the PS converter decreases the evaporation of both $\mathrm{Bi}$ and $\mathrm{Sb}$, although the $\mathrm{Sb}$ evaporation is at a much lower level than for $\mathrm{Bi}$.
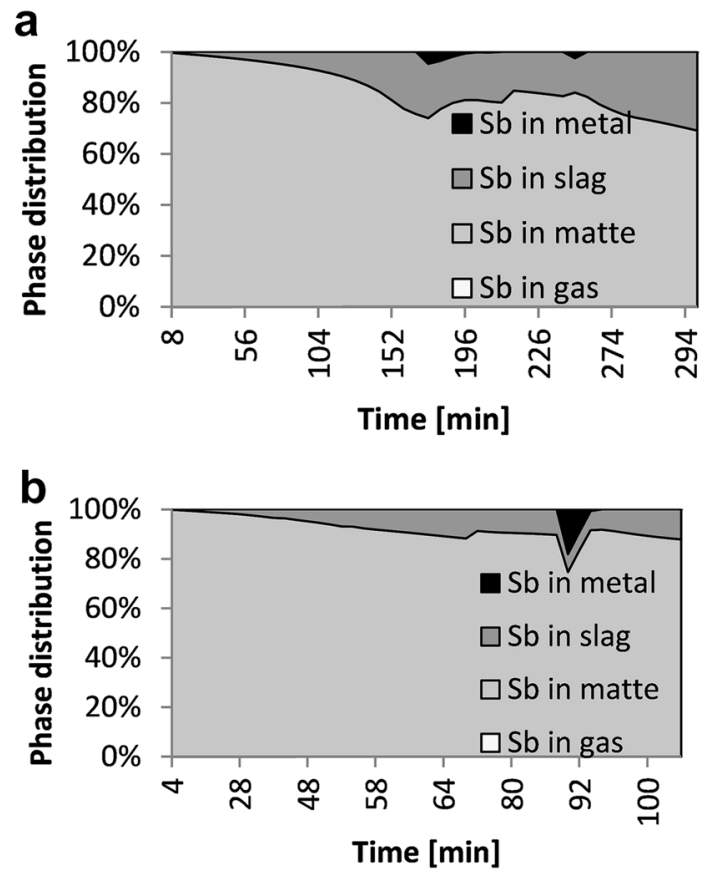

Fig. 12 Distribution of antimony between different phases for two cases considered by Lennartsson et al. [16]. Both cases with addition of black copper from smelting of WEEE in the middle of the second slag blow. Difference between a/ and b/ being the starting matte, 45 and $65 \mathrm{wt} \% \mathrm{Cu}$ in the matte, respectively. Reprinted from Thermodynamic process modeling of black copper addition to a Peirce-Smith converter: effect on the distribution of antimony and bismuth, Lennartsson et al., Mineral processing and Extractive Metallurgy (Trans. Inst. Min Metall. C), copyright The Institute of Materials, Minerals and Mining reprinted by permission of (Taylor \& Francis Ltd, http://www.tandfonline.com)

\section{Discussion}

Recycling has always been a part of most ore-based metal extraction. In addition to being necessary as a coolant in oxidative process steps, it broadens the raw material base and can within existing impurity and slag capacities contribute to the economy of the process. In this way, a wellfunctioning recycling of, e.g., precious metals, copper, lead, zinc, has long been practiced within the base metals industry, and with different types of steel within the steel industry, contributing to the sustainability of metal extraction.

At Boliden's Rönnskär plant, WEEE has been an important part of the raw-material base for several decades through campaign-wise smelting of WEEE in the Lead Kaldo plant. Since 2012, a new Kaldo plant has been operated using only WEEE as raw material, cf., Fig. 1. The capacity to smelt WEEE has thereby increased considerably, and also the flows of black copper and slag into the copper plant. Several copper smelters throughout the world use WEEE as a part of the raw-material base within existing process steps for the extraction of copper and precious metals from ores. At the Rönnskär plant, the Kaldo furnace is used for smelting, and then the molten phases are taken into the PS converter for further refining. The Aurubis, Umicore, and Metallo-Chimique plants operate mainly with scrap, with part of the charge coming from WEEE.

The recycling system in Boliden's Rönnskär plant is based on experience since the late 1970s and has proved to be very efficient in many ways. The processing is done with strict environmental control programs and tight environmental regulations. A high productivity can be maintained in the smelting furnace, as the same vessel need not be used for refining, thus maximizing the amount of material processed in the smelting of WEEE. Utilization of existing impurity capacities can be maximized and for impurities not present in high amounts in the ores, the orebased flow acts as diluting impurities coming from WEEE smelting. However, this approach also has drawbacks. Based on the experience gained through the years, operation of the copper smelting processes has been adapted for the new situation. The two perhaps most important limitations from process chemical point of view have been covered within this paper, i.e., the influence of high-melting oxides as $\mathrm{Al}_{2} \mathrm{O}_{3}$ and $\mathrm{Cr}_{2} \mathrm{O}_{3}$ on the slag chemistry and the influence of charging black copper to the PS converter on impurity removal in the converting step, e.g., antimony introduced through WEEE.

Using thermodynamic modeling it has been shown that with the levels of $\mathrm{Al}_{2} \mathrm{O}_{3}, \mathrm{Cr}_{2} \mathrm{O}_{3}$, and $\mathrm{ZnO}$ that already existed in the converter slag before the increase of the 
amount of WEEE processed in 2012, the converter slag was saturated with spinel phase. For the base case of the ESF slag, the melting temperature was also comparably high, in the order of $1300^{\circ} \mathrm{C}$. It was also shown that further increase of the $\mathrm{Cr}$ - and Al-content in the slag would increase the liquidus temperature considerably, both for ESF slag and converter slag, and especially for increased content of $\mathrm{Cr}$. A somewhat lower $\mathrm{Fe} / \mathrm{SiO} 2$ ratio could decrease the liquidus temperature of the slag, but the most striking result is the increased tolerance for $\mathrm{Al}$ and $\mathrm{Cr}$ that could be the result of a calcium ferrite slag with moderate content of FeO. A measure that can always be taken is to avoid taking the slag from the melting of WEEE together with the black copper to the PS converter. This requires, on the other hand, adequate slag chemistry in the WEEE melting to avoid excessively high metal losses to the slag and an environmentally acceptable handling of the slag. It would be very interesting to study the consequences for the whole process chain in a plant like the Rönnskär plant by changing slag compositions to a calcia-based slag, either calcium ferrite or calcia-silica-based slag. Such a study should, of course, also cover the influence of changed slag chemistry on parameters such as refractory wear, environmental properties of the final slag as well as the properties of the slag in construction applications.

The other important issue is the influence of the introduction of black copper on impurity capacities. Utilizing existing impurity capacities in an existing process system to recycle impure scrap can be a very profitable alternative. On the other hand, introducing a liquid black copper into the process system may change the impurity capacity considerably, as many of the detrimental impurities in copper making have high affinity to a liquid copper phase, thus decreasing the impurity elimination to slag and gas. In a plant that utilizes a large quantity of oxidic residues and scrap together with concentrates in the process, the matte generated from the smelting furnace might already have quite low sulfur content. Addition of liquid black copper to the PS converter may then result in a liquid copper phase being present in the converter for longer time during the slag blowing step. This was shown in the modeling of a PS converter by Lennartsson et al. [15]. The influence will, of course, depend on when, during the slag blowing, the addition is made. A conclusion is that addition of metallic secondary materials such as black copper should be made as early as possible in the slag blow, not only from an energy point of view, but also to ensure sufficient time for sulfidizing the metal by surplus sulfur in the matte. Another possible measure is to refine the metal while it is still kept in the WEEE smelting furnace, and introduce the refined liquid copper to the copper blowing step or directly cast it into anodes. This will, however, decrease the smelting capacity of the furnace, as the treatment time for each charge will be much longer.

In addition to copper, precious metals, etc., WEEE may contain a number of other metals in smaller amounts, some of them being listed as critical elements, e.g., the rare earth metals (REM). The possibility of using WEEE as a source of e.g., REM has recently attracted considerable interest. There are numerous suggestions for treatment of WEEE to extract PM, critical elements, etc., in specially designed processes using upgrading with mineral processing techniques, hydrometallurgical processing, or pyrometallurgical processes. It should, however, be emphasized that wellfunctioning economic recovery of $\mathrm{Cu}$ and $\mathrm{PM}$ from WEEE is already practiced and that any new process concept that aims at recovering, e.g., RE-metals from WEEE would not be sustainable if it jeopardizes the recovery of $\mathrm{Cu}$ and PM. A remaining big challenge for the metal recycling industry is to recover more of the elements contained in the material flows already existing within plants.

\section{Conclusions}

At Boliden's Rönnskär smelter WEEE is smelted in a Kaldo process and the black copper together or without the slag is charged to the PS converter. This process route is based on an experience going back to the late 1970s and has proven to be a viable way to obtain a high WEEE smelting capacity in an originally ore-based process system. Some of the potential drawbacks of this processing have been analyzed from process data and through thermodynamic modeling of the liquidus temperature of the slag as well as the influence on $\mathrm{Sb}$ elimination during converting. The following conclusions are based on the findings in this research:

- The introduction of impurity elements contained in WEEE influences the whole process chain within a highly interconnected process system such as the one at Boliden's Rönnskär plant.

- Introducing higher amounts of alumina and chromium to the process system through the WEEE will increase the liquidus temperature of the slag; at increased $\mathrm{Cr}$ load, the change is drastic. This is not only influencing the PS converter where the melt from WEEE smelting is charged, but also propagating to the ESF and the fuming process through recycled converter slag and refining of the smelting slag.

- Introduction of balanced amounts of lime as slag former could be one alternative to handle the risk for increased liquidus temperatures of the slag. 
- Charging of a black copper to the PS converters is an efficient way of utilizing existing impurity capacities, but with a sulfur-deficient matte from the smelting furnace there is a risk that a metal phase will form early in the processing, e.g., already during slag blowing, limiting the removal of detrimental impurities during the converting.

- Efficient recovery of the $\mathrm{Cu}$ and precious metals contained in WEEE is practiced at several plants throughout the world. In some cases, other elements are also recovered. The remaining challenge is to extract more elements out of the existing material streams without jeopardizing the recovery of copper and PM.

Acknowledgements The financial support and collaboration of Boliden Mineral AB is gratefully acknowledged. Part of the research has been financed within the Swedish Strategic Mining Research Program with support from VINNOVA. Part of the work has also been financed within CAMM, Centre of Advanced Mining and Metallurgy, at Luleå University of Technology.

Open Access This article is distributed under the terms of the Creative Commons Attribution 4.0 International License (http://crea tivecommons.org/licenses/by/4.0/), which permits unrestricted use, distribution, and reproduction in any medium, provided you give appropriate credit to the original author(s) and the source, provide a link to the Creative Commons license, and indicate if changes were made.

\section{References}

1. http://www.el-kretsen.se/pressrum. Accessed 4 Sept 2017

2. http://ec.europa.eu/eurostat/web/waste/key-waste-streams/weee. Accessed 4 Sept 2017
3. http://www.metallo.com. Accessed 4 Sept 2017

4. Roth H, Mühlenfeld J (2016) Closing the loop solutions in multimetal recycling. In: Circular materials symposium, Helsinki

5. Hagelüken C (2006) Recycling of electronic scrap at Umicore's integrated metals smelter and refinery. Erzmetall 59:152-161

6. Hagelüken C, Corti CW (2010) Recycling of gold from electronics: cost-effective use through 'Design for Recycling'. Gold Bull 43:209-220

7. http://www.montanwerke-brixlegg.com/en/. Accessed 4 Sept 2017

8. Brusselaers, J, Mark, FE, Tange, L (2006) Using metal-rich WEEE plastics as feedstock/fuel substitute for and integrated metals smelter, Technical report produced by PlasticsEurope in cooperation with Umicore and EFRA

9. Cui J, Zhang L (2008) Metallurgical recovery of metals from electronic waste: a review. J Hazard Mater 158:228-256

10. Zhang L, Wu X (2016) A review of current progress of recycling technologies for metals from waste electrical and electronic equipment. J Clean Prod 127:9-36

11. Teague KC, Swindbourne DR, Jahanshahi S (2001) A thermodynamic study on cobalt containing calcium ferrite and calcium iron silicate slags at $1573 \mathrm{~K}$. Metall Mater Trans B 32B:47-54

12. Eerola H, Jylha K, Taskinen P (1984) Thermodynamics of impurities in calcium ferrite slags in copper fire-refining conditions. Trans Inst Min Metall 93:193-199

13. Bale CW, Bélisle E, Chartrand P, Decterov SA, Eriksson G, Hack K, Jung IH, Kang YB, Melancon J, Pelton AD, Robelin C, Petersen S (2009) FactSage thermochemical software and databases - recent developments. Calphad 33:295-311

14. Samuelsson C, Björkman B (1998) Dust forming mechanisms in the gas cleaning system after the copper converting process: (II) thermodynamic studies. Scand J Metall 27:64-72

15. Lennartsson A, Engström F, Björkman B, Samuelsson C (2013) Development of a model for copper converting. Can Metall Q 52:422-429

16. Lennartsson A, Engström F, Björkman B, Samuelsson C (2014) Thermodynamic process modeling of black copper addition to a Peirce-Smith converter. Effect on the distribution of antimony and bismuth. Miner Proc Extr Metall 123:157-164

17. Lennartsson A, Engström F, Björkman B, Samuelsson C (2015) Characterization of buildup in an electric furnace for smelting copper concentrates. Can Metall Q 54:477-484 